\title{
Adjustments to Accounting Profit in Determination of the Income Tax Base: Evolution in the Czech Republic $^{\#}$
}

\author{
Ladislav Mejzlík ${ }^{*}-$ Leoš Vitek ${ }^{* *}-$ Jana Roe
}

\section{Introduction}

One of the expected impacts of the economic recession in 2009 was an increase in corporate taxation in developed countries as a response to the need for additional tax revenue and negative voter sentiment aimed in particular on the financial sector. However, it appears that European Union (EU) countries, during the financial and economic crisis, continued the existing trend of mostly declining tax bases, rates and also provided relief with respect to the timing of tax payments. Work on a common corporate tax base in the EU continues, albeit with less intensity. More than ten years ago (2001) the European Commission (EC) has opened further round of discussions regarding the proposal of a common consolidated corporate tax base, including whether and how to reform corporate taxation at the European level. First steps

\# This article has been prepared under the research project Assumptions for Introduction of the IFRS as an Alternative Tax Base in a Small Open Economy: Evaluation of Its Impact on Country's Competitiveness supported by the Czech Science Foundation under the registration number $\mathrm{P} 403 / 12 / 1901$.

* doc. Ing. Ladislav Mejzlík, Ph.D. - Associate Professor; Faculty of Finance and Accounting, University of Economics, Prague, W. Churchill Sq. 4, 130 67 Prague, Czech Republic; <lmejzlik@vse.cz>.

** doc. Ing. Leoš Vítek, Ph.D. - Associate Professor; Faculty of Finance and Accounting, University of Economics, Prague, W. Churchill Sq. 4, 13067 Prague, Czech Republic; <leos.vitek@vse.cz>.

*** Jana Roe, Ph.D., CPA - Lecturer; Faculty of Finance and Accounting, University of Economics, Prague, W. Churchill Sq. 4, 13067 Prague, Czech Republic; <xroej900@vse.cz>. 
after initiating work on this proposal were directed towards the analysis of the potential use of International Financial Reporting Standards (IFRS) as a starting point for determining the tax base. As emphasized for example by Schön (2004), IFRS are accounting standards, which were adopted as a common framework for companies listed on stock exchanges and therefore are the best starting point for a common European tax base. Further steps towards a common European tax base went in another direction (Nerudová, 2012) and neither the Member States nor the EU eventually supported the use of IFRS as a framework for the calculation of the tax base.

Nevertheless, the issue of using IFRS as a starting point for calculating the tax base remains highly current. The main reason for considering this option is the fact that listed companies in the EU must use IFRS for the preparation of their financial statements; therefore the tax bases that are calculated using accounting result computed according to national rules cause additional costs. The problem is also compounded by the fact that a substantial portion of corporate income tax revenue in EU countries is generated by companies that use IFRS.

Examples of literature focused on the connection between tax base and tax revenues include research by Dwenger and Steiner (2012), who are examining the relationship between tax base and statutory tax rate for Germany using tax return data. Creedy and Gemmell (2010) examined a sample of British companies using micro-simulation, studying the response of tax base and tax deductions to the changes in statutory corporate tax rates. Devereux (2006) and Loretz (2008) in their analyses also focus on the link between corporate profits and tax base.

Eberhartinger and Klostermann (2006) analyzed in detail the impact of the potential switch from Austrian GAAP to IFRS on the tax liability and showed on a sample of 61 companies in a variety of scenarios that only in a few cases there were substantial differences in taxation after the transition to IFRS. Guggiola (2010) summarizes the application of IFRS and harmonization of accounting policies in the EU and performs meta-analysis of the literature on this topic.

Jirásková (2013) compared the 35 entities using IFRS mandatorily and 106 large corporate taxpayers in the Czech 
Republic and analysed the impact of IFRS and national accounting rules on tax bases and tax revenues. Blechova (2012) analysed financial and tax accounting of firms in the EU and its harmonization. The development of financial reporting in the Czech Republic and its regulation in the EU, including its relationship to various tax aspects discussed Ištvánfyová et al (2010). For example Mejzlík (2006) addressed in detail the issue of possible conversion methods between national accounting systems and IFRS and the associated risks.

This article aims to describe the main trends in income, tax base and tax deductions for Czech companies in years 1993 2012. The structure of this paper is as follows: after an initial survey of the problem and prior research literature, the paper describes the issue of national accounting policy regulation in relation to IFRS and shows the evolution of main macroeconomic indicators of profitability and corporate taxation in the EU and the Czech Republic. The following section is based on data from the Ministry of Finance of the Czech Republic and monitors the development of corporate accounting profits, tax bases and tax deductions. All data collected for the purposes of this article were available only on an annual accrual basis as an aggregate; therefore it is not possible to draw any conclusions for any specific groups of companies or sectors. The concluding section summarizes the main findings of the paper and offers suggestions for further research.

\section{Accounting profit and tax base: regulation via either national rules or IFRS}

The system of national accounts, part of which are Czech Accounting Standards or CAS, and its regulation in the Czech Republic is based on the traditions of continental Europe, especially France and Germany. It is regulated via legislation formed by the government, specifically the parliament. The world trend in the last few decades, including in continental Europe, is the growing influence of the Anglo-Saxon system of accounting regulation.

Until 1989, the accounting and tax regulation in the Czech Republic (including accounting and tax laws) were completely interconnected. It was only after the economic system reform in 
1989, when the first Czech Accounting Act was created, and together with concurrent tax reform, specifically changes in substantive and procedural tax law, the process of separating accounting and tax regulation began (Müller and Mejzlík, 2007).

In 2005, this process acquired a new dimension due to the implementation of IFRS into Czech accounting law. The change was made in accordance with the EU decision regarding the mandatory adoption of IFRS for the preparation of consolidated financial statements of European listed companies at the latest by January 2005 (by January 2007 for companies that issue publicly traded debt). The result of a process of gradual separation of tax and accounting regulation is an accounting system, which is in principle divided into four categories of companies and corresponding rules.

Tab. 1: Accounting system in the Czech Republic

\begin{tabular}{|l|c|c|}
\hline \multicolumn{1}{|c|}{$\begin{array}{c}\text { Size/type of } \\
\text { company }\end{array}$} & $\begin{array}{c}\text { Applicable } \\
\text { accounting } \\
\text { rules }\end{array}$ & Specific issues \\
\hline $\begin{array}{l}\text { Publicly traded } \\
\text { large companies }\end{array}$ & IFRS & $\begin{array}{c}\text { Traded on a stock } \\
\text { exchange, } \\
\text { mandatory audit, } \\
\text { consolidation of } \\
\text { foreign subsidiaries }\end{array}$ \\
\hline $\begin{array}{l}\text { Mid-size firms: } \\
\text { audited } \\
\text { Mid-size firms: } \\
\text { not audited }\end{array}$ & CAS & Mandatory audit \\
\cline { 2 - 3 } Small firms & CAS & $\begin{array}{c}\text { Simplified } \\
\text { double-entry } \\
\text { bookkeeping }\end{array}$ \\
\hline Sole proprietors & $\begin{array}{c}\text { Tax evidence } \\
\text { based on cash } \\
\text { basis } \\
\text { bookkeeping }\end{array}$ & $\begin{array}{c}\text { Most frequently } \\
\text { only for tax } \\
\text { purposes }\end{array}$ \\
\hline
\end{tabular}

Source: Modified from original version by Mejzlík and Pelák (2008). 
Due to Czech Republic's membership in the EU, the country had to harmonize its accounting rules with EU law, specifically the 4th, the 7th and the 8th EU Directives and adopt IFRS starting in 2005. However, accounting rules continue to be edited even on the EU level (for example Žárová, 2010); therefore, it is to be expected that the accounting rules for businesses will continue to evolve at both European and national level.

In the Czech Republic, the usage of IFRS is mandatory for the preparation of financial statements of any entity that issues securities listed on a regulated stock market. According to the tax law, these companies must use financial results determined by CAS as the starting point for determining their tax base, without taking into account their use of IFRS. Even in this area in recent years, steps are being taken to limit the link between accounting and taxation.

Conversely, companies that do not meet the above condition of being publicly traded, were not allowed to use IFRS, even voluntarily, and had to compile their financial statements according to CAS, even in cases, where they were a part of a consolidated group and had to submit their financial statements to their parent company compiled in accordance with IFRS for the purposes of compiling the consolidated financial statements of the group. In this case, the company must fulfil the obligation under the Czech Accounting Act and compile their financial statements in accordance with CAS and subsequently convert their financial statements to IFRS to comply with reporting of the parent company or other users who require financial statements according IFRS.

Czech accounting standards are based on an entirely different conceptual framework than IFRS. Financial statements prepared in accordance with CAS versus IFRS are mutually incompatible. Financial reporting according to CAS leads to other data reported in the financial statements, which are therefore not comparable either for one company in various accounting periods or between various companies for the same accounting period. There are many differences between IFRS and CAS, the main are in the following areas: 
- revenue recognition,

- lease reporting,

- business combinations,

- provisions,

- financial instruments,

- interim financial reporting.

However, differences also exist in other areas, such as fixed assets and their impairment, receivables, payables, etc. Compared to IFRS, Czech regulations require that the face of financial reports contain more detailed information; where in financial reports prepared according to IFRS, such information is normally presented in the notes to financial statements (for example depreciation, amortization and provisions). As a result, statements prepared in accordance with IFRS often appear to be more concise. However, the IFRS rules regarding required disclosures in notes to financial statements are stricter than under CAS.

The Czech Accounting Act allows entities that prepare separate stand-alone financial statements according to CAS the option to prepare consolidated financial statements according to IFRS. If an entity does not use the IFRS option, it must prepare its consolidated financial statements according to CAS. The rules for consolidation procedures are very similar between CAS and IFRS; however, the consolidated financial statements prepared to CAS versus IFRS are not comparable. The reason is that despite the similarity in the consolidation rules themselves, the individual financial statements included in the consolidation differ between CAS and IFRS.

For the purposes of internationally comparing accounting profits, tax bases and tax liabilities, several sources must be utilized. Accounting profit is not included in either EU or OECD statistical reports. Instead, national accounts use the concept of gross operating surplus (GOS), which according to ESA 95, reflects the excess of a firm's operating revenues after deducting the cost purchases and labour. Theoretically, GOS represents the resources available to enterprises for the repayment of loans, payment of taxes and financing capital expenditures. 
If consumption of fixed capital (CFC) is deducted from GOS, the result is net operating surplus (NOS). At the level of entrepreneurs and small businesses this measure is used after deducting CFC as gross mixed income (GMI) or net mixed income (NMI); therefore, due to technical reasons, small businesses do not distinguish between operating income and income from equity and are presented together (hence mixed).

\section{Fig. 1: Gross operating surplus: relative annual increase (EU27 and the Czech Republic)}

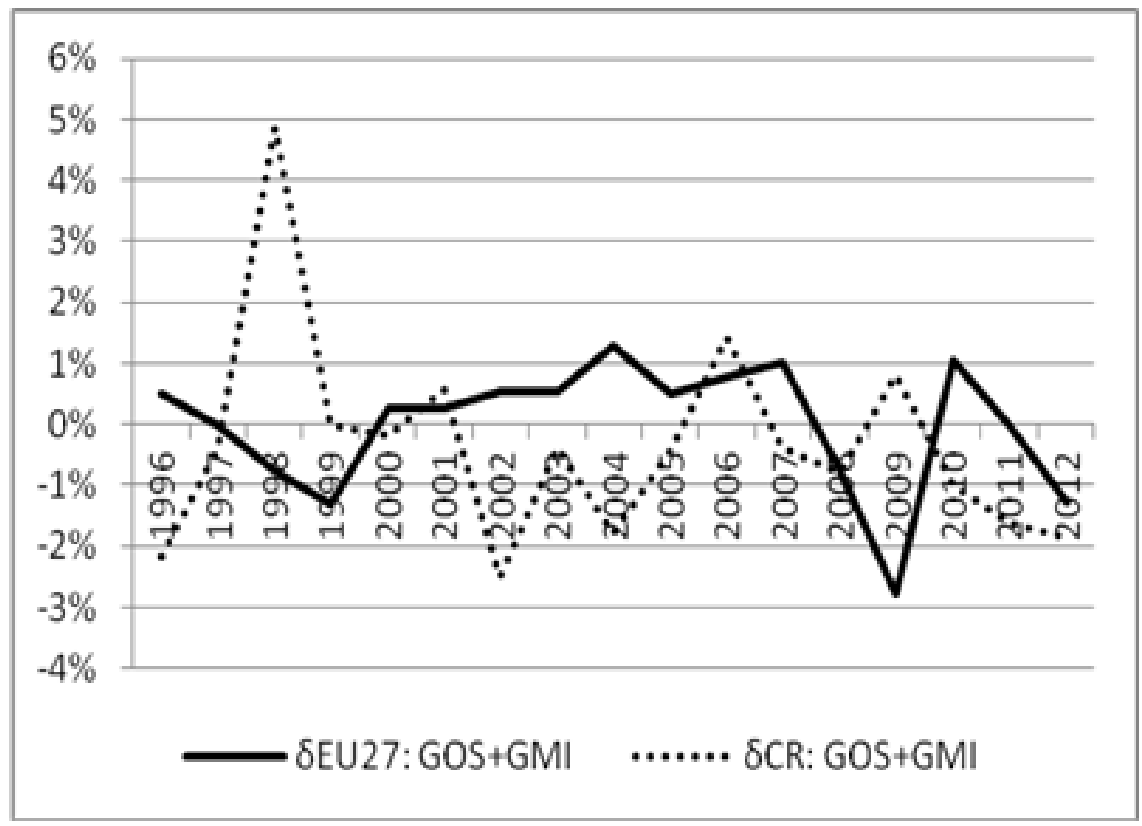

Source: Graf was created by authors using data from EC (2013).

Note: $\delta=$ relative increase in $\%$, GOS = gross operating surplus, GMI = gross mixed income.

Gross operating surplus in the Czech Republic changed in the last two decades more than the average in the EU27. Fluctuations in late 1990s in the Czech Republic are related to the investment cycle, specifically depreciation. Starting in 2006, there is an apparent correspondence between the Czech and EU27 cycles, when changes in the Czech Republic were by approximately one year preceding changes in the EU. In 2009, the GOS in the Czech Republic did not fall below zero, because it already reached 
negative values one year earlier. However, during the last three years, the Czech values were lower than the average in Europe.

Data on corporate tax bases is available from EC (2013a). The tax base is presented as a percentage of GDP, and the following chart shows the relative increase for the EU27 and the Czech Republic.

\section{Fig. 2: Corporate tax base: relative annual increase (EU27 and the Czech Republic)}

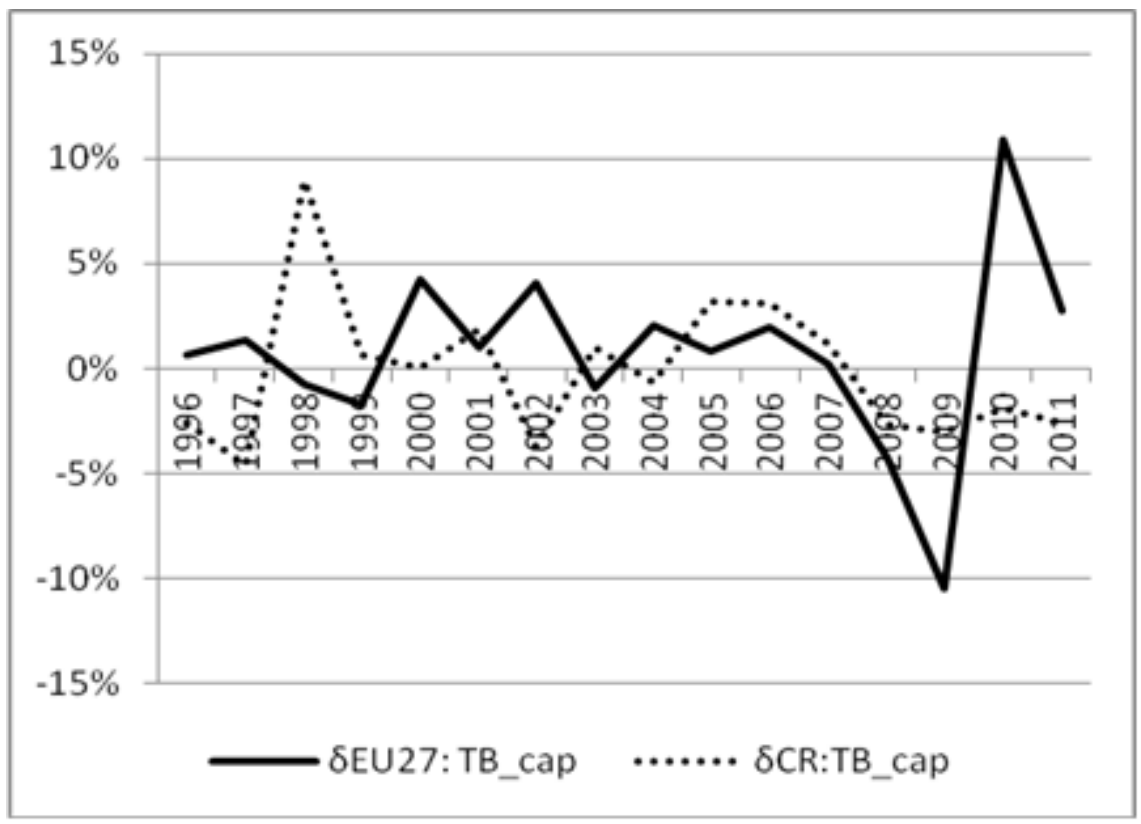

Source: Graf was created based on data from EC (2013a).

Note: $\delta=$ relative increase in $\%$, TB_cap $=$ corporate tax base in $\%$ of GDP.

The relative change in tax base in the EU in years 2008 2009 was much larger than in the Czech Republic. This also applies for years 2010 - 2011, when the tax base in the EU had increased significantly, while in the Czech Republic it steadily decreased starting in 2008. In the next section we will examine, whether the situation in the Czech Republic is a consequence of reduced profitability of firms or the effect of tax legislation making adjustments to income tax base. 
The implicit tax rate (ITR) is often used to measure the effective taxation of production factors such as labour or capital. In EC (2013a), ITR is also used to evaluate the effective taxation of consumption and energy. ITR generally expresses the ratio of applicable taxes to the subject of taxation, for example payroll refunds, returns on capital, consumption, etc. For corporations, ITR measures the share of total tax revenues from corporate taxes to total capital revenues related to businesses.

Data for the implicit tax rate on corporations are not available for the period examined in this paper. Instead, for comparison with developments in the Czech Republic, the EU17 Eurozone countries average, for which Eurostat publishes the implicit tax rate, was used.

Fig. 3: Implicit tax rate on capital and business income of firms: relative annual increase (EU17 and the Czech Republic)

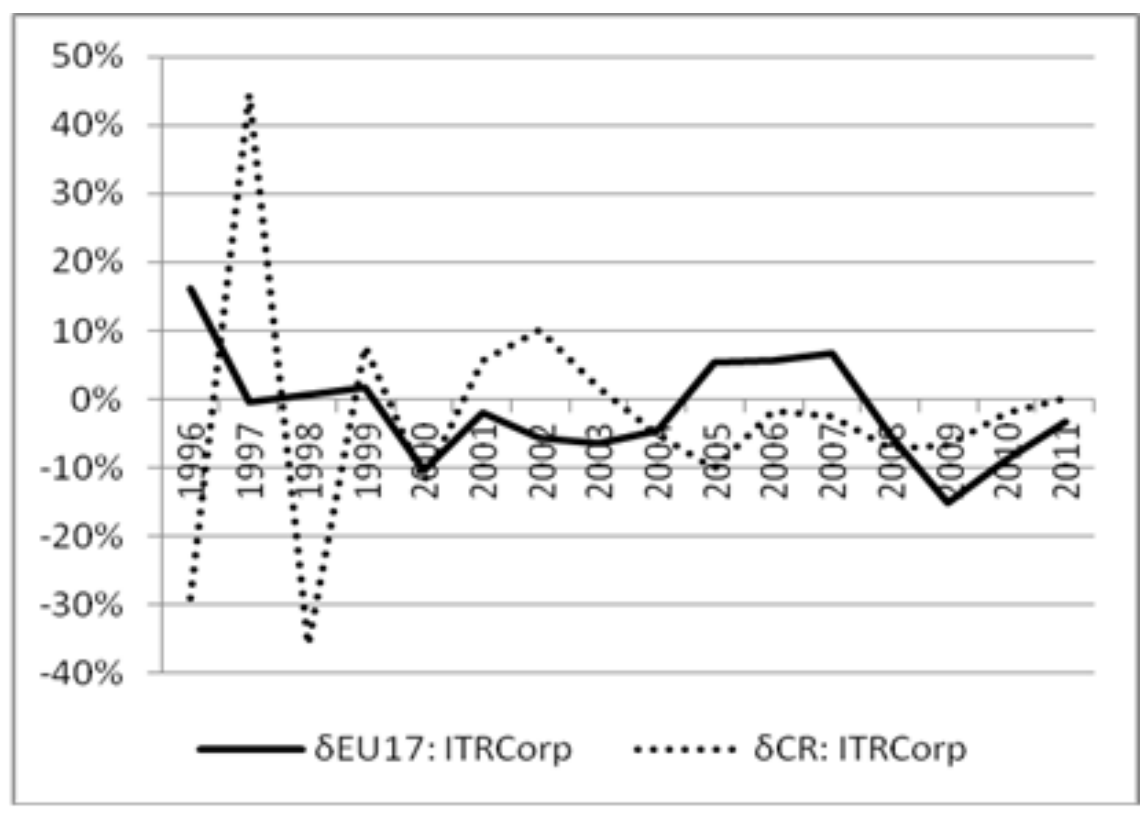

Source: Graf was created based on data from EC (2013a).

Note: $\delta=$ relative increase in \%, ITRCorp = implicit tax rate on corporations.

The effective corporate tax rate expressed in terms of ITR has been falling during the past 10 years in the Czech Republic; 
however, in 2009-2011 the ITR was significantly reduced in the entire group of EU17 countries. Reasons for the decline are both ad hoc government actions to support businesses as part of the anti-crisis measures and also long-term changes in fiscal policy reducing effective corporate taxation.

\section{Accounting profit and tax base: development in the Czech Republic}

As shown by Vítek (2013) and the following table of longterm time-period series of interval indicators, accounting profit, tax base and items decreasing/increasing accounting profit in computation of the tax base, since the establishment of the Czech Republic the tax bases of companies are more influenced by the tax adjustment to accounting profit rather than fluctuation of accounting profit itself. While it is true that tax adjustments to accounting profit (both items deducted and added back to accounting profit to arrive at the tax base) largely offset each other, their balance is not negligible and in various years significantly affects the tax base. This is confirmed in the following table, which shows the amounts that decrease/increase accounting profits when calculating the tax base.

Tab. 2: Accounting profit and tax adjustments for the Czech Republic

\begin{tabular}{|l|r|r|r|r|r|r|r|}
\hline & $\mathbf{2 0 0 0}$ & $\mathbf{2 0 0 5}$ & $\mathbf{2 0 0 8}$ & $\mathbf{2 0 0 9}$ & $\mathbf{2 0 1 0}$ & $\mathbf{2 0 1 1}$ & $\mathbf{2 0 1 2}$ \\
\hline $\begin{array}{l}\text { Accounting profit (in } \\
\text { billion CZK) }\end{array}$ & 86 & 485 & 593 & 534 & 192 & 211 & 287 \\
\hline $\begin{array}{l}\text { Total adjustments in } \\
\text { computing tax base } \\
\text { (in billion CZK) }\end{array}$ & 51 & 10 & 48 & 21 & 365 & 358 & 279 \\
\hline $\begin{array}{l}\text { Total adjustments in } \\
\text { computing tax base } \\
\text { (\% of accounting } \\
\text { profit) }\end{array}$ & 59 & 2 & 8 & 4 & 190 & 170 & 97 \\
\hline
\end{tabular}

Source: Table created by author using data from Ministry of Finance (2013).

In all the years since 1993, tax adjustments increasing accounting profit exceeded tax adjustments decreasing accounting profit in the tax base computation. The largest difference between 
the amount of accounting profits and related tax adjustments existed in the first decade after the introduction of the new tax system. As the following table shows, in this period, the average accounting profit was rather small and therefore tax adjustments decreasing or increasing accounting profit were comparatively high.

\section{Tab. 3: Accounting profit, tax adjustments decreasing and increasing accounting profit, tax base and tax liability: average values for the Czech Republic (billions CZK)}

\begin{tabular}{|l|r|r|r|}
\hline & \multicolumn{1}{|c|}{$\begin{array}{c}\text { 1993- } \\
\mathbf{2 0 1 2}\end{array}$} & \multicolumn{1}{c|}{$\begin{array}{c}\text { 1993- } \\
\mathbf{2 0 0 2}\end{array}$} & \multicolumn{1}{c|}{$\begin{array}{c}\text { 2003- } \\
\mathbf{2 0 1 2}\end{array}$} \\
\hline Accounting profit (loss) & 194 & -16 & 404 \\
\hline $\begin{array}{l}\text { Tax adjustments increasing } \\
\text { profit }\end{array}$ & 646 & 474 & 818 \\
\hline $\begin{array}{l}\text { Tax adjustments decreasing } \\
\text { profit }\end{array}$ & -517 & -346 & -687 \\
\hline Tax base & 324 & 113 & 535 \\
\hline Tax liability & 96 & 68 & 124 \\
\hline
\end{tabular}

Source: Table created by author using data from Ministry of Finance (2013).

The comparison in table 3 also shows that in the second decade of the current corporate tax regime in the Czech Republic, changes occur to the significance of tax adjustments. Although accounting profits significantly increased in the second decade, the tax liability only doubled. In other words, the average tax adjustments increasing profit rose $73 \%$ between the two decades, and the average tax adjustments decreasing profit rose $99 \%$.

Without additional detailed data, it is not possible to clearly identify the reasons for this development; however, in principle, it is possible to consider a number of factors causing these phenomena. One possibility is that the legislature gradually relaxes the rules for deductibility of income and expenses (policy of narrowing the tax base). The second possibility is that in the second decade, taxpayers better utilized aggressive tax planning compared to the first decade of the new tax system, i.e. more efficiently used the possibility to reduce accounting profit while calculating the tax base (or, conversely not including certain 
accounting revenues in the tax base). The third option is changes in real economical processes that cause this development.

The following graphs illustrate the dynamics between accounting profit and related tax base. The first graph showing annual absolute difference suggests that variances in the accounting profit ( $\triangle$ Profit) are usually larger than variances in the tax base $(\triangle \mathrm{TB})$. One of the factors that generally acts as divergence between accounting profit, tax base and tax liability is the gradual (not one-time) utilization of tax losses in the tax base. If this mechanism works, it would result in smaller tax liability in the following few years. This effect can be decomposed due to the five-year tax loss carry-over period and the problematic development of the economy (and therefore lower profits and related small tax bases) through 2015 .

Using data and information from the servers of the Czech Ministry of Finance, it is not possible to precisely determine why items increasing accounting profit in determining the tax base totalled more than 550 billion CZK in years 2010 on. This increase was labelled as "other cases not included above," which is somewhat vague and difficult to interpret.

Conversely, tax deductions of more than 200 billion CZK can be quite unambiguously traced to the item "income not subject to tax for taxpayers not established for business purposes." Regardless, such a dramatic jump in this item is difficult to justify and will require more detailed analysis. 
Fig. 4: Accounting profit and tax base: total and annual changes

for the Czech Republic

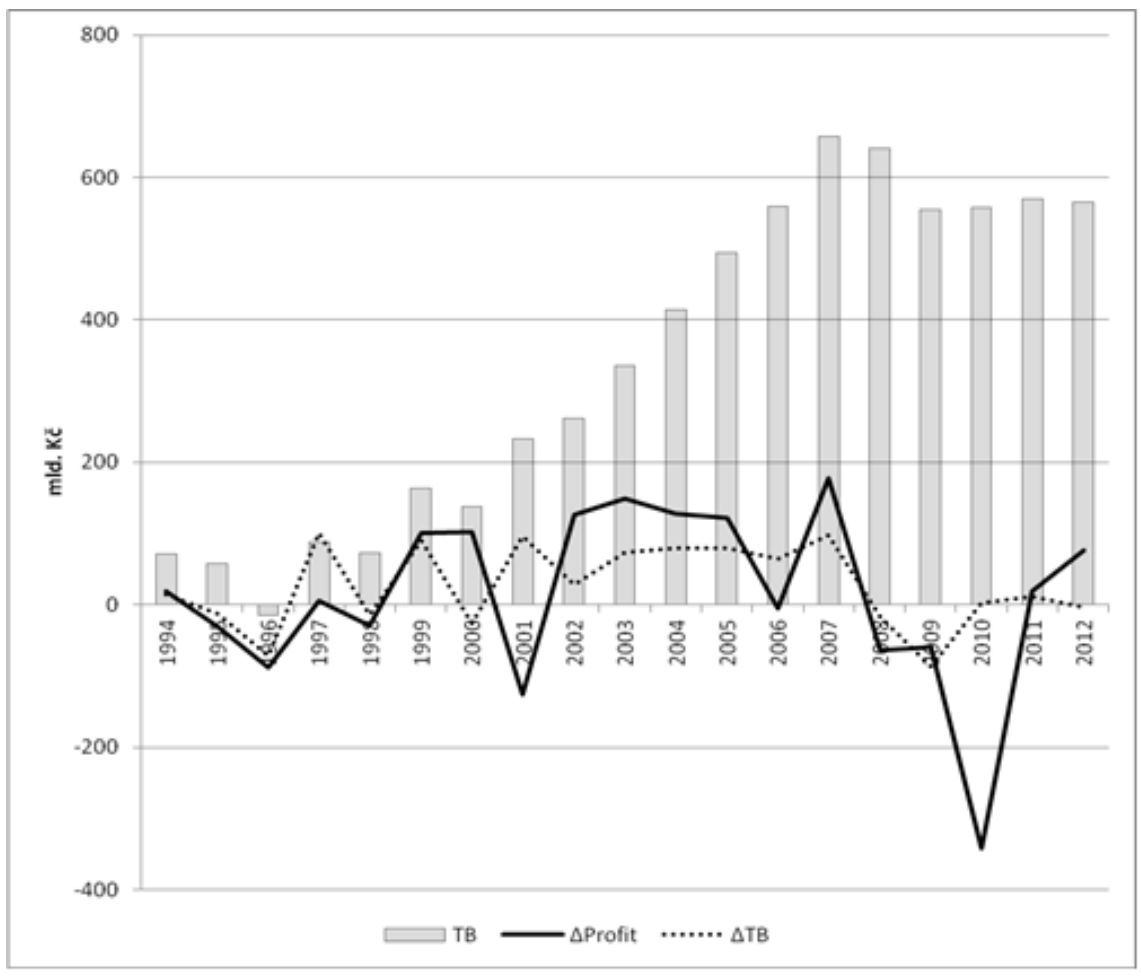

Source: Graph created by author using data from Ministry of Finance (2013).

Note: $\Delta=$ absolute difference, $\mathrm{TB}=$ tax base, Profit $=$ accounting profit.

In the early years after the introduction of the corporate tax (1993 - 2000), the changes to accounting profits were more closely related to the overall size of the tax base than in recent years. The first decade is also marked by the high volatility of accounting profits and tax bases; probably due to the transformation shocks in the early 1990s. The second factor of the volatility relates to the macroeconomic developments in 19971998 (economic growth slowdown) and in 2001 (decrease in demand for Czech exports due to slowing growth in Germany), which had a significant impact on accounting profits and tax bases of companies. In the period from 2000 to 2007, the tax base is constantly growing, which allowed for increase in corporate tax revenues, even with a decline in tax rates from $35 \%$ in 1999 to 
the current $19 \%$ (effective from 2010). Starting in 2008, however, tax liability reported by companies fell by $35 \%$, with no significant change in the tax rate, which fell only from $21 \%$ to $19 \%)$.

An interesting development in the tax base occurs during years $1999-2002$, when the tax base, with approximately oneyear delay partially follows the development of accounting profits, but in 2000 the direction reversed resulting in opposite development. Similarly, in 2009 - 2010, corporate profits fell sharply, but the corporate tax base increased. This indicates a delayed response of the tax base or result of the restrictive conditions for the transfer of corporate operating results into the tax base. However, the development in 2012 (data not definitive) shows that despite the growth in accounting profits, tax bases remain substantially the same, which supports the hypothesis a delayed response of the tax bases to the development of accounting profits.

The second graph shows, using the relative changes in GDP, accounting profits and tax base, a more detailed illustration of the development in the second decade after the introduction of the Czech corporate tax. The left axis shows accounting profits and taxable income or loss after adjustments, right axis shows changes in GDP. 
Fig. 5: Relative increases in GDP (right axis) and the income tax base TB (left axis) for the CR

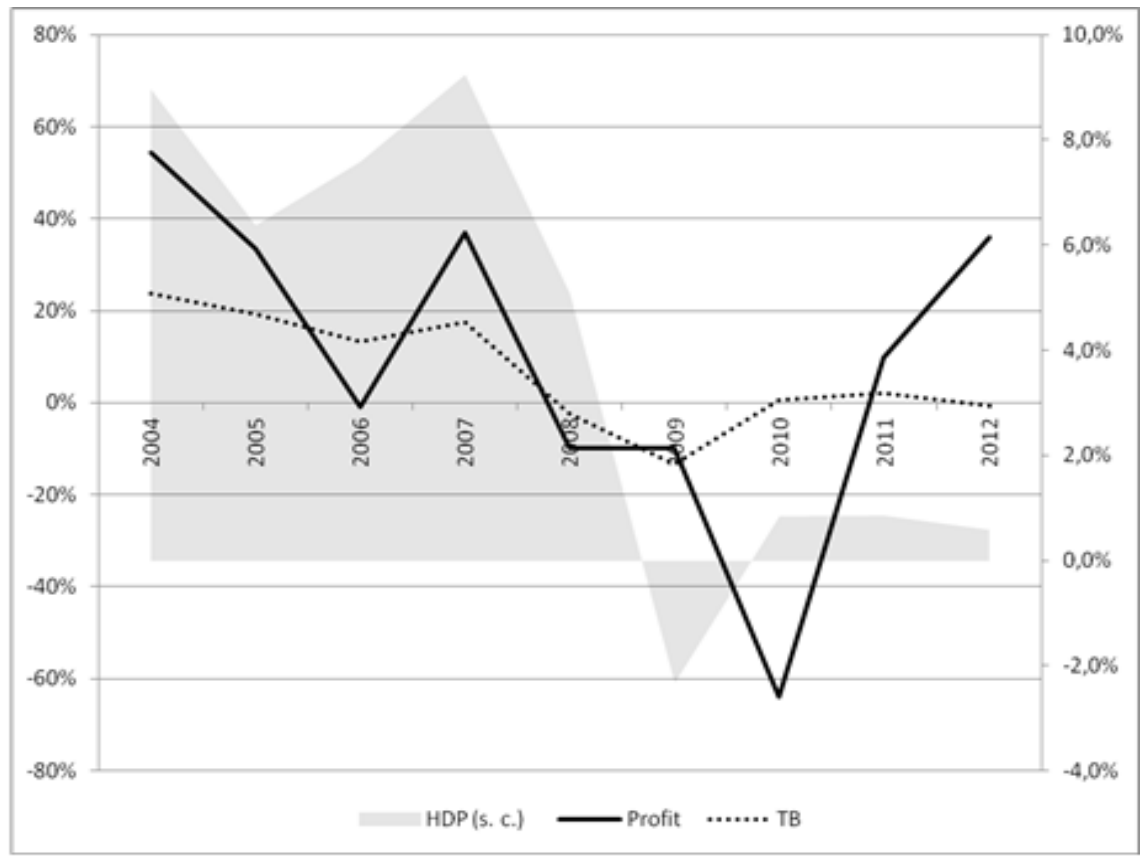

Source: Graph created using data from Ministry of Finance (2013) and CSO (2013).

The tax base and its development depend on many factors, for example as discussed by Kubátová and Ř́íhová (2009), Devereux et al. (2004) and Vítek (2013). The principal factors include economic development, the number of taxpayers and accounting and tax rules. In the Czech Republic, there is no clear link between the tax liability and the number of taxpayers, for example in the 1990s the number of taxpayers often increased, but the overall tax burden declined. It is also difficult to find a clear link between the tax liability and the statutory tax rate. The connection is evident for the growth of GDP and increase in corporate accounting profits. However, as a result of administrative changes to accounting profits in arriving at the tax base, this relationship is relatively weak for GDP, tax base and tax liability.

To view the development trend of accounting earnings, tax adjustments and tax base, it is possible to use multiple 
approaches. In this paper, the simplest option is selected, using the smoothing of time series adjusted by moving averages, where using the simple arithmetic average of the values is the entire time series compensated in portions. The length of the moving average selected here is three years.

The main trend observed for accounting profits in recent years was a steady growth until 2009, since when profits are continuously decreasing. The tax base, which grew at the same rate as accounting profits until 2009, is declining in subsequent years only very slightly. This is due to the rapid increase in items increasing accounting profit and slower growth in profit-reducing items.

Fig. 6: Accounting profit, items decreasing and increasing profit and tax base: three-year moving average for the CR

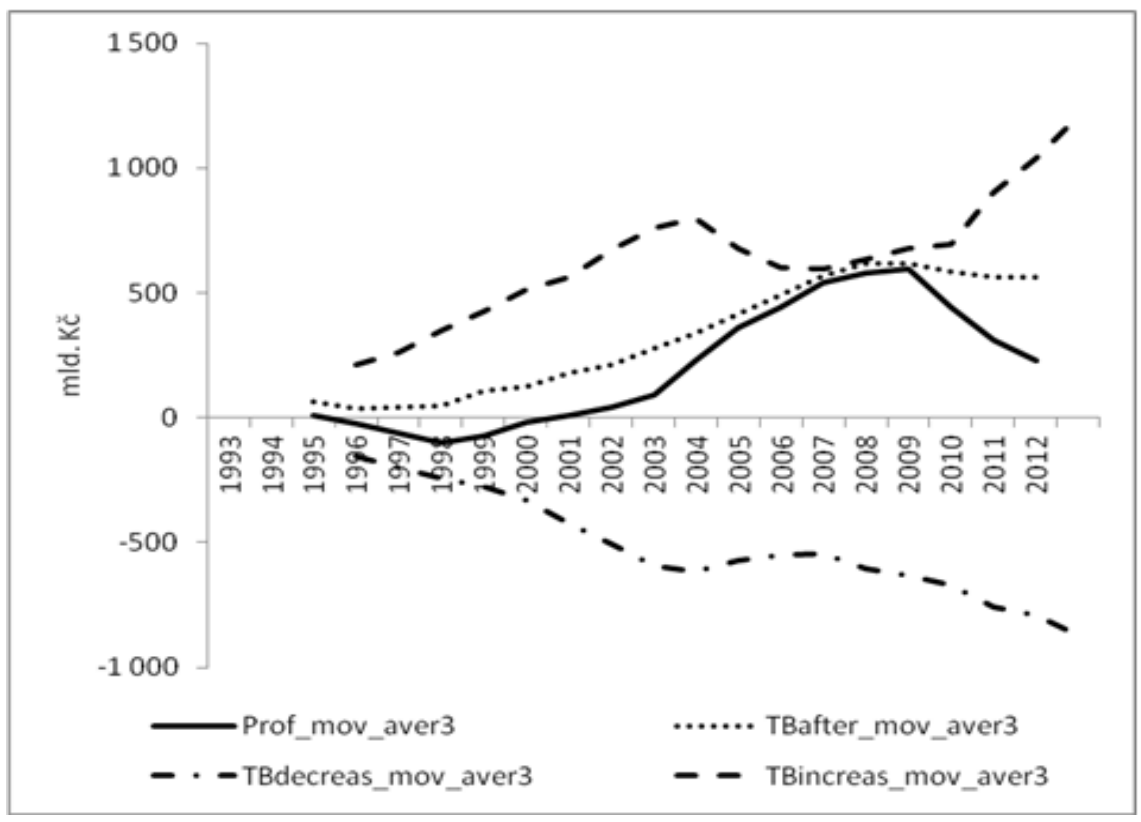

Source: Graph was created using data from Ministry of Finance (2013).

Note: mov_aver $3=$ three-year moving average, Prof $=$ profit, TBdecreas $=\operatorname{tax}$ adjustments reducing profit, TBincreas $=$ tax adjustments increasing profit, TBafter $=$ tax base. 


\section{Conclusion}

Allowing the use of international financial reporting standards for the compilation of financial statements also carries with it implications for the areas of taxation and national accounting legislation. On the one hand, the use of IFRS better facilitates the consolidation of results for multinational corporations by reducing the costs of accounting and financial reporting. It also helps investors in making more rational decisions about their investments. On the other hand, IFRS brought into the discussions on tax policy a fundamental question: should governments allow companies to abandon national accounting rules and calculate their results using only IFRS? If this were to happen, governments would de facto loose control of reporting for not only accounting profits, but also tax base, which is more or less closely dependent on accounting results. As Schön (2004) points out, most characteristics of IFRS are consistent with the objectives of corporate and individual taxation. However, according to the author, problems are encountered in the area of investments, financial instruments and the concept of "fair value". The author argues that the basic features and functions of IFRS can be used to fulfil the objectives of the tax laws and therefore can be used for the purposes of corporate taxation.

Data needed for the analysis of corporate profits is not publicly available from either Eurostat or OECD. Access to the database Amadeus is very expensive and does not include all companies. Therefore, it is necessary to use the indicator GOS as an approximation of accounting earnings, which strongly fluctuates in the last five years in the EU27 and in the Czech Republic. Corporate tax bases fluctuate even strongly in Europe in the same time whereas implicit tax rates fluctuate less strongly.

To evaluate the potential impacts of changes to the accounting and financial reporting rules, is important to note that tax adjustments during the time period $2000-2009$ did not total a significant amount. However, since 2010, the total of tax adjustments has grown dramatically and is now significantly affecting corporate income tax revenues in the Czech Republic. Research also shows, that the relative impact of tax adjustments was stronger in the first decade after the introduction of the new tax system, in absolute terms they are rapidly growing especially 
in the last 5 years. Tax adjustments reducing accounting profit are growing relatively quickly.

The final conclusion drawn from the findings of this paper is that the rules for determining the tax base, in comparison with accounting rules, mitigate the fluctuation of tax base, especially in years 2010 and 2012. In the short term, this effect may lead to further widening of the gap between accounting profit and tax base.

\section{References}

Blechova, B (2012): The Analysis of the Corporate Financial and Tax Accounting in the EU and their Harmonization. In Cervinek, P. (ed.): European Financial Systems 2012. Brno: Masaryk Univ, Fac. Econom \& Adm, pp. 12-17, 2012.

Creedy, J. - Gemmell, N. (2010): Modelling Responses to Profit Taxation over the Economic Cycle: The Case of the UK Corporation Tax. Finanzarchiv, 2010, vol. 66, no. 3, pp. 207-235. ČSÚ (2013): Hrubý domácí produkt - Časové rady ukazatelů čtvrtletních účtů. [on-line], Praha, Český statistický úřad, 2013 [cite $1^{\text {st }}$ October 2013], <http://www.czso.cz/csu/redakce.nsf/ i/hdp_cr>.

Devereux, M. P. - Griffith, R. - Klemm, A. (2004): Why Has the UK Corporation Tax Raised So Much Revenue? Fiscal Studies, 2004, vol. 25, no. 4, pp. 367-388.

Devereux, M. P. (2006): Developments in the Taxation of Corporate Profit in the OECD since 1965: Rates, Bases and Revenues. [on-line], Oxford, Oxford University Centre for Business Taxation Working Paper 07/04, 2006, [cite $5^{\text {th }}$ November 2012], <http://ideas.repec.org/p/btx/wpaper/0704. html>.

Dwenger, N. - Steiner, V. (2012): Profit Taxation and the Elasticity of the Corporate Income Tax Base: Evidence from German Corporate Tax Return Data. National Tax Journal, 2012, vol. 65, no. 1, pp. 117-150.

Eberhartinger, E. - Klostermann, M. (2006): What if IAS/IFRS were a Tax Base? New Empirical Evidence from an Austrian Perspective. [on-line], Vienna, Institut für Revisions, Treuhand und Rechnungswesen, WU Vienna University of Economics and 
Business, Working Papers 01, 2006, [cite $10^{\text {th }}$ August 2012], <http://epub.wu.ac.at/1096/>.

EC (2013): European Commission - Eurostat Database. GDP and main components - Current prices [nama_gdp_c] and Implicit tax rates by economic function [gov_a_tax_itr]. [on-line], Brussels, European Commission - Eurostat, [cited $9^{\text {th }}$ October 2012], <http://epp.eurostat.ec.europa.eu/portal/page/portal/ statistics/search_database $>$.

EC (2013a): Taxation trends in the European Union. 2013 edition. Luxembourg: Publications Office of the European Union, 2013.

Guggiola, G. (2010): IFRS Adoption in the E.U., Accounting Harmonization and Markets Efficiency: A Review. International Business \& Economics Research Journal, vol. 9, no. 12, pp. 99112.

Ištvánfyová, J. - Mejzlík, L. - Pelák, J (2010): Progression of Financial Reporting in Czech Republic and its Regulation. European Financial and Accounting Journal, 2010, vol. 5, no. 1, pp. 64-77.

Jirásková, S. (2013): Range of data reported to the requirements of the IAS 12 and impact of the IFRS adoption for tax purposes in the tax collection of the Czech Republic. Acta Universitatis Agriculturae et Silviculturae Mendelianae Brunensis, 2013, vol. 61, no. 4, pp. 961-966.

Kubátová, K. - Ř́hová, L. (2009): Regresní analýza faktorů ovlivñujících výnosy korporativní daně v zemích OECD. Politická ekonomie, 2009, vol. 57, no. 4, pp. 451-470.

Loretz, S. (2008): Corporate taxation in the OECD in a wider context. [on-line], Oxford, Oxford University Centre for Business Taxation Working Paper 08/21, 2008, [cite $5^{\text {th }}$ September 2012], <http://ideas.repec.org/p/btx/wpaper/0821.html>.

Mejzlík, L. - Pelák, J. (2008): Czech Accounting Regulation - The Way From Communism to European Union Membership. In 12th World Congress of Accounting Historians (WCAH). Istanbul, AVCIOL, pp. 162, 2008.

Mejzlík, L. (2006): Možnosti a rizika technologického řšení prevodu českých účetních závěrek do IFRS. VŠE v Praze: Český finanční a účetní časopis, vol. 1, no. 1, pp. 84-98. 
MF (2013): Automatizovaný daňový informační systém (databáze). Praha: Ministerstvo financí ČR, 2013.

Müllerová, L. - Mejzlík, L. (2007): Jaké jsou aktuální otázky vývoje účetnictvi? Účetnictví, 2007, vol. 7, pp. 54-55.

Nerudová, D. (2012): Common consolidated corporate tax base: Grouping and consolidation. Acta Universitatis Agriculturae et Silviculturae Mendelianae Brunensis, 2012, vol. 60, no. 2, pp. 237-244.

Schön, W. (2004): International Accounting Standards - A Starting Point for a Common European Tax Base? European Taxation, 2004, vol. 44, no. 10, pp. 426-440.

Vítek, L. (2013): Zdanění firem a jejich daňový základ $v \check{C} R$. Český finanční a účetní časopis, vol. 8, no. 2, pp. 38-49 (in print).

Žárová, M. (2010): Revize účetnich směrnic. Český finanční a účetní časopis, 2010, vol. 5, no. 1, pp. 7-19. 


\title{
Adjustments to Accounting Profit in Determination of the Income Tax Base: Evolution in the Czech Republic
}

\begin{abstract}
The article analyzes the main trends in income, tax base and tax deductions for Czech companies in years 1993 - 2012. After an initial survey of the problem, the article describes the issue of national accounting policy regulation in relation to IFRS and shows the evolution of main macroeconomic indicators of profitability and corporate taxation in the EU and the Czech Republic. The following part is based on data from the Ministry of Finance of the Czech Republic and monitors the development of corporate accounting profits, tax bases and tax deductions. All data collected for the purposes of this article were available only on an annual accrual basis as an aggregate; therefore it is not possible to draw any conclusions for any specific groups of companies or sectors. The concluding section summarizes the main findings of the paper and offers suggestions for further research.
\end{abstract}

Key words: IFRS; Tax base; Czech Republic.

JEL classification: M41, H25 